\section{Tillage, Cover Cropping, and Nitrogen Fertilization Influence Tomato Yield and Nitrogen Uptake}

\author{
Upendra M. Sainju', Bharat P. Singh, and Syed Rahman \\ Agricultural Research Station, Fort Valley State University, Fort Valley, \\ GA 31030-3298
}

\author{
V.R. Reddy \\ U.S. Department of Agriculture, Agricultural Research Service, National \\ Research Institute Remote Sensing and Modelling Laboratory, Beltsville, \\ MD 20705
}

Additional index words. Lycopersicon esculentum, hairy vetch, Vicia villosa, fruit production

\begin{abstract}
Management practices can influence tomato (Lycopersicon esculentum Mill.) yield and $\mathrm{N}$ uptake. The effects of tillage (no-till, chisel plowing, and moldboard plowing), cover crop [hairy vetch (Vicia villosa Roth) vs. none], and $\mathrm{N}$ fertilization $(0,90$, and 180 $\mathrm{kg} \cdot \mathrm{ha}^{-1} \mathrm{~N}$ ) on transplanted tomato yield and $\mathrm{N}$ uptake were studied in the field from May to August in 1996 and 1997 on a Norfolk sandy loam (fine-loamy, siliceous, thermic, Typic Kandiudults) in central Georgia. Plowing increased fresh and dry fruit yield and $\mathrm{N}$ uptake in 1996 and $N$ fertilization increased yield and $N$ uptake in 1996 and 1997. Plowing also increased stem and leaf dry weights and $N$ uptake from 40 to 118 days after transplanting (DAT) in 1996. Fertilization increased stem weight and $N$ uptake with or without hairy vetch from 54 to $68 \mathrm{DAT}$ in 1996 and stem and leaf weights and $N$ uptake at 68 DAT in 1997. Both hairy vetch and $N$ fertilization increased leaf $N$ concentration in 1997. Recovery of $\mathbf{N}$ by the plants was lower with hairy vetch than with $\mathbf{N}$ fertilization, but was similar to or greater with 90 than with $180 \mathrm{~kg} \cdot \mathrm{ha}^{-1} \mathrm{~N}$. We conclude that reduced tillage, such as chisel plowing, with $90 \mathrm{~kg} \cdot \mathrm{ha}^{-1} \mathrm{~N}$ can sustain tomato yield and $\mathrm{N}$ uptake, with reduced potentials of sediments and/or $\mathrm{NO}_{3}$ contamination in surface and groundwater.
\end{abstract}

Poor agronomic practices, accompanied by excessive $\mathrm{N}$ fertilization, increase soil erosion and $\mathrm{NO}_{3}$ pollution potential in surface and groundwater (Hallberg, 1989; Linville and Smith, 1971). In Georgia, farming-associated $\mathrm{NO}_{3}$ pollution of groundwater is often a problem (Berndt, 1993). Vegetable cropping systems require a greater degree of management and utilize a larger $\mathrm{N}$ input than most agronomic cropping systems (Power and Schepers, 1989). Also, vegetables recover less $\mathrm{N}$ than do agronomic crops (Lowrance and Smittle, 1988), thus the potential for $\mathrm{NO}_{3}$ loss is greater with the former. Therefore, management practices that sustain vegetable production and improve soil and water quality are needed.

Tillage accelerates soil erosion and $\mathrm{N}$ mineralization, thereby increasing the potential for sediment and $\mathrm{NO}_{3}$ pollution in surface and groundwater (Legg and Meisinger, 1982; Randall, 1990; Yadav, 1997). Similarly, $\mathrm{NO}_{3}$ leaching increases with increasing $\mathrm{N}$ fertilization (Owens et al., 1994; Pang et al., 1998; Sexton et al., 1996). In contrast, cover crops planted in the fall, following a summer crop, recycle residual $\mathrm{NO}_{3}$ and reduce its potential

Received for publication 14 May 1999. Accepted for publication 10 Aug. 1999. The cost of publishing this paper was defrayed in part by the payment of page charges. Under postal regulations, this paper therefore must be hereby marked advertisement solely to indicate this fact.

${ }^{1}$ To whom reprint requests should be addressed. e-mail:sainjuu@mail.fvsu.edu for leaching (Meisinger et al., 1990, 1991; Sainju et al., 1998). Legume cover crops can also fix $\mathrm{N}$ from the atmosphere, thereby enriching soil $\mathrm{N}$, increasing succeeding crop yield, and reducing the amount of $\mathrm{N}$ fertilization required for succeeding crops (Frye et al., 1988; Kuo et al., 1996; Sainju and Singh, 1997).

Tomato is an important vegetable crop in Georgia. In order to reduce groundwater pollution under vegetable crops, more sustainable cultural practices that maintain or improve groundwater quality without significantly decreasing crop yields need to be developed. Our objectives were to 1) determine the growth rate, yield, and $\mathrm{N}$ uptake by transplanted tomato as influenced by tillage, hairy vetch cover cropping, and $\mathrm{N}$ fertilization, and 2) compare $\mathrm{N}$ recovery by tomato from $\mathrm{N}$ supplied by hairy vetch residue vs. $\mathrm{N}$ fertilization.

\section{Materials and Methods}

The experiment was conducted for 2 years at the Agricultural Research Station farm, Fort Valley State Univ., Fort Valley, Ga., on a Norfolk sandy loam (fine-loamy, siliceous, rainfall data were collected from a weather station, $20 \mathrm{~m}$ from the experimental site.

The treatments included three levels of tillage (no-till, chisel plowing, and moldboard plowing), two levels of cover crop (hairy vetch thermic, Typic Kandiudults). Temperature and vs. no hairy vetch), and three levels of $\mathrm{N}$ fertilization $\left(0,90\right.$, and $\left.180 \mathrm{~kg} \cdot \mathrm{ha}^{-1} \mathrm{~N}\right)$. Prior to chisel plowing (15- to $20-\mathrm{cm}$ depth), plots were harrowed (15- to 20-cm depth). After plowing, they were leveled with an S-tine harrow (10- to $15-\mathrm{cm}$ depth). Similarly, conventional tillage (moldboard plowing) consisted of harrowing (15- to 20-cm depth), followed by moldboard plowing (20- to $25-\mathrm{cm}$ depth) and leveling (10- to $15-\mathrm{cm}$ depth). Notill plots were left undisturbed except during planting of cover crop and tomatoes, when lines were drawn with a seed drill. The treatments were arranged in a split-split plot design where tillage was used as main plot, cover crop was used as split plot, and $\mathrm{N}$ fertilization as split-split plot. Each treatment had three replications, with a split-plot size of $7.2 \times 7.2 \mathrm{~m}$.

On 17 Sept. 1995 and 11 Oct. 1996, chisel and moldboard plots were harrowed, tilled, and leveled. No-till plots were left undisturbed except for drilling of cover crop seed. Hairy vetch seed was drilled at $28 \mathrm{~kg} \cdot \mathrm{ha}^{-1}$, with a row spacing of $15 \mathrm{~cm}$. No fertilizer, herbicide, or pesticide was applied to the cover crop. On 11 Apr. 1996 and 3 Apr. 1997, hairy vetch at the flowering stage was harvested from two 900$\mathrm{cm}^{2}$ areas within each plot for determination of dry matter yield and N concentration. Data for the two areas were pooled. In the no-vetch treatment, weeds [dominated by henbit (Lamium amplexicaule L.) and cut-leaf evening primrose (Oenothera laciniata L.)] were collected as above. Plant materials were ovendried for $3 \mathrm{~d}$ at $60^{\circ} \mathrm{C}$, weighed, and ground to pass a 1-mm screen. After sampling, cover crop and weeds were mowed in all plots with a rotary mower. Residues in the no-till plots were killed by spraying with $3.36 \mathrm{~kg} \cdot \mathrm{ha}^{-1}$ of glyphosate [ $N$-(phosphonomethyl) glycine], and incorporated into the soil by harrowing in the other plots. They were allowed to decompose in the soil for 2 weeks before transplanting tomatoes.

On 25 Apr. 1996 and 17 Apr. 1997, P (from triple superphosphate) and $\mathrm{K}$ (from $\mathrm{KCl}$ ) were broadcast each at the rate of $56 \mathrm{~kg} \cdot \mathrm{ha}^{-1}$ based on the soil test in all plots, along with $67 \mathrm{~kg} \cdot \mathrm{ha}^{-}$ ${ }^{1}$ of 5\% diazinon [diethyl 0-(2-isopropyl-6 methyl-4 pyrimidinyl) phosphorothioate] granule to control cutworms and $0.57 \mathrm{~kg} \cdot \mathrm{ha}^{-1}$ of trifluralin [2,6, dinitro- $N, N$-dipropyl-4(trifluoromethyl) benzeneamine] to control weeds. In the tilled plots, fertilizers, pesticide, and herbicide were incorporated into the soil by plowing. Using a planter, lines were drawn $0.9 \mathrm{~m}$ apart in all plots, and holes $(15 \mathrm{~cm}$ in diameter $\times 15 \mathrm{~cm}$ deep) were dug at every 0.9 $\mathrm{m}$ in the lines where 5-week-old tomato ('Sunbeam') seedlings were hand-transplanted. The spacing of $0.9 \times 0.9 \mathrm{~m}$ in flat beds was used to produce large (marketable) fruit (Univ. of Georgia, 1995). Starter solution containing $\mathrm{N}-\mathrm{P}-\mathrm{K}$ was applied $\left(0.4 \mathrm{~kg} \cdot \mathrm{ha}^{-1}\right.$ each $)$ to each tomato plant after 1 week to encourage rapid establishment. Nitrogen fertilizer was applied in three equal quantities and each application was broadcast at 3-week intervals from the date of transplanting. A reel rain gun applied $25 \mathrm{~mm}$ of water immediately after fertilization and during tomato growth as needed to pre- 
vent moisture stress. Irrigation was applied at $2,12,21,32,42$, and $63 \mathrm{~d}$ after transplanting (DAT) in 1996 and at 2, 11, 21, and 42 DAT in 1997.

To determine the rate of dry matter accumulation, two tomato plants $\left(1.62-\mathrm{m}^{2}\right.$ area) were harvested every 2 weeks from middle rows in each plot from 7 June to 30 Aug. 1996 and from 27 May to 21 Aug. 1997. Plants were separated into stems, leaves, and fruits; dried at $60{ }^{\circ} \mathrm{C}$; weighed; and ground to pass a $1-\mathrm{mm}$ screen for $\mathrm{N}$ analysis. In addition, fruits were harvested from five plants $\left(4.05-\mathrm{m}^{2}\right.$ area $)$ from two center rows every 3 to $4 \mathrm{~d}$ in July and Aug. 1996 and 1997, as the color turned from green to pink. Fruits were weighed, cut into slices, oven-dried at $60^{\circ} \mathrm{C}$, and weighed again to determine fresh and dry yields. The dried fruits were ground, composited, and a subsample was used for $\mathrm{N}$ analysis.

The $\mathrm{N}$ concentration in the cover crop and tomato stem, leaf, and fruit samples was determined by the $\mathrm{H}_{2} \mathrm{SO}_{4}-\mathrm{H}_{2} \mathrm{O}_{2}$ method as described by Kuo et al. (1997b). The C concentration in the cover crop sample was determined by the wet digestion method as described by Kuo et al. (1997a). The $\mathrm{N}$ accumulation in the cover crop was calculated by multiplying dry matter biomass yield by $\mathrm{N}$ concentration. Similarly, $\mathrm{N}$ uptake in tomato stems, leaves, and fruits was calculated by multiplying the dry weight by $\mathrm{N}$ concentration. Nitrogen recovered by tomato was calculated as follows:

$$
\begin{gathered}
\text { Nitrogen recovery }(\%)= \\
\left(\mathrm{N}_{\mathrm{ut}}-\mathrm{N}_{\mathrm{uc}}\right) \times 100 /\left(\mathrm{N}_{\mathrm{st}}-\mathrm{N}_{\mathrm{sc}}\right)
\end{gathered}
$$

where $\mathrm{N}_{\mathrm{ut}}=$ tomato $\mathrm{N}$ uptake with hairy vetch or 90 or $180 \mathrm{~kg} \cdot \mathrm{ha}^{-1} \mathrm{~N}, \mathrm{~N}_{\mathrm{uc}}=$ tomato $\mathrm{N}$ uptake with no hairy vetch or $0 \mathrm{~kg} \cdot \mathrm{ha}^{-1} \mathrm{~N}, \mathrm{~N}_{\mathrm{st}}=\mathrm{N}$ supplied by hairy vetch or 90 or $180 \mathrm{~kg} \cdot \mathrm{ha}^{-1} \mathrm{~N}$, and $\mathrm{N}_{\mathrm{sc}}=\mathrm{N}$ supplied by no hairy vetch (weeds) or $0 \mathrm{~kg} \cdot \mathrm{ha}^{-1} \mathrm{~N}$.

Tomato stem, leaf, and fruit data were analyzed statistically using the MIXED procedure of SAS containing fixed and random effects (Littell et al., 1996). Sources of variation included tillage, cover crop, $\mathrm{N}$ fertilization, sampling date, and their interactions. The least square means test was used to determine significant differences between the means when treatments and their interactions were significant. Statistical significance was evaluated at $P \leq 0.05$.

\section{Results and Discussion}

Climate. In 1996, average daily temperature (ADT) increased steadily from $14.1^{\circ} \mathrm{C}$ at 7 DAT to $27.6^{\circ} \mathrm{C}$ at 37 DAT, dropped to 20.0 ${ }^{\circ} \mathrm{C}$ at $45 \mathrm{DAT}$, and then peaked at $29.8^{\circ} \mathrm{C}$ at 77 DAT (Fig. 1A). In 1997, the increase in ADT during early tomato growth was more gradual than in 1996. It increased from $10.0^{\circ} \mathrm{C}$ at 2 DAT to $24.1^{\circ} \mathrm{C}$ at 39DAT, dropped to $17.1^{\circ} \mathrm{C}$ at $52 \mathrm{DAT}$, and then peaked at $29.8^{\circ} \mathrm{C}$ at 78 DAT (Fig. 1B). As a result, ADT from 0 to 78 DAT was $3.0^{\circ} \mathrm{C}$ greater in 1996 than in 1997. Total rainfall from 0 to 120 DAT was $406 \mathrm{~mm}$ in 1996 and $610 \mathrm{~mm}$ in 1997 (Fig. $1 \mathrm{C}$ and D). Most of the rain in 1997 fell from 40 to 120 DAT.

1996
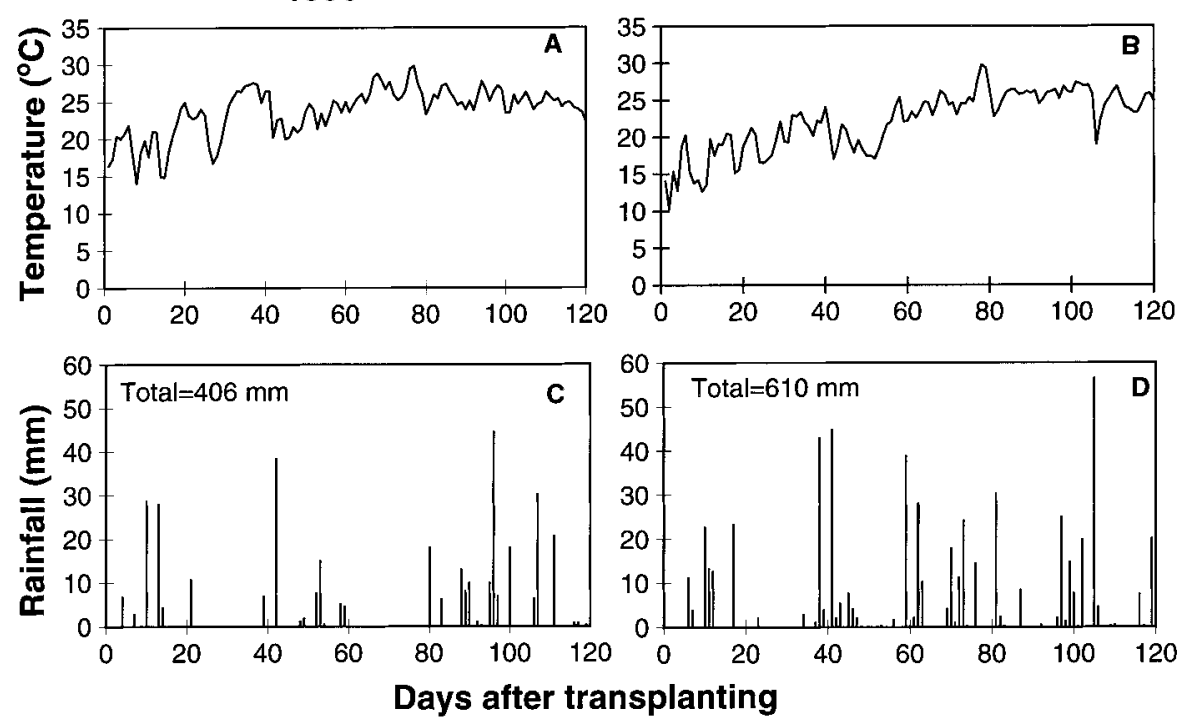

Fig. 1. Average daily temperature and total daily rainfall during tomato growth near the experimental site in 1996 and 1997.

\begin{tabular}{|c|c|c|c|c|c|c|c|c|}
\hline \multirow{2}{*}{$\begin{array}{l}\text { Cover } \\
\text { crop }\end{array}$} & \multicolumn{2}{|c|}{$\begin{array}{c}\text { Biomass yield } \\
\left(\mathrm{Mg} \cdot \mathrm{ha}^{-1}\right)\end{array}$} & \multicolumn{2}{|c|}{$\begin{array}{c}\text { N concn } \\
\left(\mathrm{g} \cdot \mathrm{kg}^{-1}\right)\end{array}$} & \multicolumn{2}{|c|}{$\begin{array}{c}\mathrm{N} \text { accumulation } \\
\left(\mathrm{kg} \cdot \mathrm{ha}^{-1}\right)\end{array}$} & \multicolumn{2}{|c|}{$\mathrm{C}: \mathrm{N}$ ratio } \\
\hline & 1996 & 1997 & 1996 & 1997 & 1996 & 1997 & 1996 & 1997 \\
\hline Hairy vetch & $5.47 \mathrm{a}^{\mathrm{z}}$ & $4.16 \mathrm{a}$ & $37.5 \mathrm{a}$ & $18.5 \mathrm{a}$ & $206 a$ & $77 \mathrm{a}$ & $11.7 \mathrm{a}$ & $23.6 \mathrm{a}$ \\
\hline $\begin{array}{l}\text { No hairy vetch } \\
\text { (weeds) }\end{array}$ & $1.94 \mathrm{~b}$ & $1.90 \mathrm{~b}$ & $18.7 \mathrm{~b}$ & $14.1 \mathrm{~b}$ & $37 \mathrm{~b}$ & $27 \mathrm{~b}$ & $18.0 \mathrm{~b}$ & $32.3 \mathrm{~b}$ \\
\hline
\end{tabular}

Table 1. Biomass yield, $\mathrm{N}$ concentration, $\mathrm{N}$ accumulation, and C:N ratio of cover crops in 1996 and 1997.

${ }^{\mathrm{z}}$ Mean separation within columns by the least square means test, $P \leq 0.05$.

Cover crop yield, nitrogen concentration, and nitrogen accumulation. Dry matter yield, $\mathrm{N}$ concentration, and $\mathrm{N}$ accumulation in cover crops were not significantly influenced by tillage (data not shown). As expected, biomass yield was 2- to 3 -fold greater and $\mathrm{N}$ concentration and accumulation were 1.5 - to 6-fold greater in hairy vetch than in no hairy vetch (or weeds) (Table 1). As a result, C:N ratio of hairy vetch was also lower than that of weeds without hairy vetch. Nitrogen accumulated in cover crops was greater in 1996 than in 1997 due to higher $\mathrm{N}$ concentration.

Tomato fruit yield and nitrogen uptake. Fresh and dry fruit yield and $\mathrm{N}$ uptake were significantly influenced by tillage in 1996 and $\mathrm{N}$ fertilization in 1996 and 1997 (Table 2). Cover crop and its interaction with tillage or $\mathrm{N}$ fertilization did not influence fruit yield and $\mathrm{N}$ uptake (data not shown). Similarly, fruit number and $\mathrm{N}$ concentration were not influenced by tillage, cover crop, or $\mathrm{N}$ fertilization (Table 2).

Fresh and dry fruit yield and $\mathrm{N}$ uptake were significantly lower in no-till than in plowed plots in 1996 (Table 2), but were not significantly affected by the method of plowing. In contrast, $\mathrm{N}$ fertilization significantly increased fresh and dry fruit yield and N uptake in 1996 and 1997, with no significant difference between 90 and $180 \mathrm{~kg} \cdot \mathrm{ha}^{-1} \mathrm{~N}$.

Increased soil compaction and/or development of root restricting layers could have limited root growth, thereby reducing fruit yield and N uptake in no-till plots in 1996. Singh and Sainju (1998) observed that the number of tomato roots per $\mathrm{cm}^{2}$ soil profile from 19.5- to 58.5-cm depth in 1996 was $65 \%$ greater in moldboard-plowed than in no-till plots. Increased soil bulk density (a sign of increasing compaction) from transition of conventional tillage to no-till was observed by several researchers (Kaspar et al., 1991; McCarty et al., 1998; Wander et al., 1998). The compaction or development of root restricting layers in no-till results from incomplete amelioration of compacted soil over the winter (Bauder et al., 1981; Voorhees, 1983). In 1997, however, fresh and dry fruit yield and $\mathrm{N}$ uptake were not affected by tillage. Effects of tillage on crop yield were reported by several researchers (Dao, 1993; Kaspar et al., 1991; Merrill et al., 1996; Rao and Dao, 1996). Our data suggest that chisel plowing is as effective as moldboard plowing in tomato production; however, chisel plowing may be more effective in reducing soil erosion and $\mathrm{N}$ mineralization.

Increased $\mathrm{N}$ availability from $\mathrm{N}$ fertilization may have increased fruit yield and $\mathrm{N}$ uptake, as observed by several researchers (Melton and Dufault, 1991b; Weston and Zandstra, 1989; Widders, 1989). The similar fruit yield and $\mathrm{N}$ uptake with $90 \mathrm{vs} .180 \mathrm{~kg} \cdot \mathrm{ha}^{-1}$ $\mathrm{N}$ indicates that the lower rate can produce sustainable tomato yield. The $180 \mathrm{~kg} \cdot \mathrm{ha}^{-1} \mathrm{~N}$ rate is excessive for tomato in central Georgia and therefore should be discontinued. Reducing the rate of $\mathrm{N}$ fertilization will also reduce the potential for $\mathrm{NO}_{3}$ leaching into groundwater.

Fruit number was lower but yield and N uptake were greater in 1996 than in 1997 (Table 2), perhaps because of differences in 
Table 2. Effects of tillage and N fertilization on tomato fruit number, fresh and dry yield, and N concentration and uptake in 1996 and 1997.

\begin{tabular}{|c|c|c|c|c|c|c|c|c|c|c|}
\hline \multirow[b]{3}{*}{ Treatment } & \multirow{2}{*}{\multicolumn{2}{|c|}{ Fruit no./plant }} & \multicolumn{4}{|c|}{ Yield $\left(\mathrm{Mg} \cdot \mathrm{ha}^{-1}\right)$} & \multirow{2}{*}{\multicolumn{2}{|c|}{$\begin{array}{c}\text { N concn } \\
\left(\mathrm{g} \cdot \mathrm{kg}^{-1}\right)\end{array}$}} & \multirow{2}{*}{\multicolumn{2}{|c|}{$\begin{array}{l}\text { N uptake } \\
\left(\mathrm{kg} \cdot \mathrm{ha}^{-1}\right)\end{array}$}} \\
\hline & & & \multicolumn{2}{|c|}{ Fresh } & \multicolumn{2}{|c|}{ Dry } & & & & \\
\hline & 1996 & 1997 & 1996 & 1997 & 1996 & 1997 & 1996 & 1997 & 1996 & 1997 \\
\hline \multicolumn{11}{|l|}{$\overline{\text { Tillage }^{z}}$} \\
\hline NT & $18.7 \mathrm{a}^{\mathrm{y}}$ & $40.3 \mathrm{a}$ & $35.0 \mathrm{a}$ & $32.1 \mathrm{a}$ & $1.32 \mathrm{a}$ & $1.68 \mathrm{a}$ & $38.5 \mathrm{a}$ & $40.9 \mathrm{a}$ & $50.6 \mathrm{a}$ & $69.1 \mathrm{a}$ \\
\hline $\mathrm{CH}$ & $25.7 \mathrm{a}$ & $34.9 \mathrm{a}$ & $66.4 \mathrm{~b}$ & $33.5 \mathrm{a}$ & $2.48 \mathrm{~b}$ & $1.69 \mathrm{a}$ & $37.8 \mathrm{a}$ & $37.9 \mathrm{a}$ & $93.8 \mathrm{~b}$ & $64.3 \mathrm{a}$ \\
\hline MB & $25.9 \mathrm{a}$ & $39.8 \mathrm{a}$ & $62.9 \mathrm{~b}$ & $30.5 \mathrm{a}$ & $2.44 \mathrm{~b}$ & $1.66 \mathrm{a}$ & $35.8 \mathrm{a}$ & $38.8 \mathrm{a}$ & $86.9 \mathrm{~b}$ & $63.1 \mathrm{a}$ \\
\hline \multicolumn{11}{|c|}{$\mathrm{N}$ fertilization $\left(\mathrm{kg} \cdot \mathrm{ha}^{-1}\right)$} \\
\hline 0 & $22.8 \mathrm{a}$ & $36.7 \mathrm{a}$ & $49.5 \mathrm{a}$ & $26.6 \mathrm{a}$ & $1.83 \mathrm{a}$ & $1.32 \mathrm{a}$ & $38.0 \mathrm{a}$ & $39.1 \mathrm{a}$ & $69.1 \mathrm{a}$ & $51.8 \mathrm{a}$ \\
\hline 90 & $22.6 \mathrm{a}$ & $40.2 \mathrm{a}$ & $58.1 \mathrm{~b}$ & $36.0 \mathrm{~b}$ & $2.20 \mathrm{~b}$ & $1.86 \mathrm{~b}$ & $37.1 \mathrm{a}$ & $39.9 \mathrm{a}$ & $82.4 \mathrm{~b}$ & $73.1 \mathrm{~b}$ \\
\hline 180 & $25.0 \mathrm{a}$ & $38.1 \mathrm{a}$ & $56.6 \mathrm{~b}$ & $33.6 \mathrm{~b}$ & $2.22 \mathrm{~b}$ & $1.87 \mathrm{~b}$ & $37.0 \mathrm{a}$ & $38.7 \mathrm{a}$ & $80.0 \mathrm{~b}$ & $71.7 \mathrm{~b}$ \\
\hline \multicolumn{11}{|l|}{ Significance $^{\mathrm{x}}$} \\
\hline Tillage & NS & NS & $* *$ & NS & $* *$ & NS & NS & NS & $* *$ & NS \\
\hline $\mathrm{N}$ fertilization & NS & NS & $*$ & $* *$ & $*$ & $* * *$ & NS & NS & $*$ & $* * *$ \\
\hline
\end{tabular}

${ }^{2} \mathrm{NT}$ denotes no-till; $\mathrm{CH}$, chisel plowing; and $\mathrm{MB}$, moldboard plowing.

${ }^{y}$ Mean separation within columns and factors by the least square means test, $P \leq 005$.

${ }^{x}$ Sources of variation that were nonsignificant are excluded.

ns, ${ }^{*}, *, * * *$ Nonsignificant or significant at $P \leq 0.05,0.01$, and 0.001 , respectively.

temperature and rainfall patterns (Fig. 1). Increased ADT from 0 to 78 DAT may have resulted in setting of larger but fewer fruits in 1996 than in 1997, thereby increasing fruit yield and $\mathrm{N}$ uptake. Temperature can influence tomato yield (Melton and Dufault, 1991a; Teasdale and Abdul-Baki, 1995). Drier conditions from 0 to 80 DAT in 1996 (Fig. 1C) were compensated for by timely irrigation, but excessive rainfall from 40 to 120 DAT in 1997 (Fig. 1D) may have limited fruit growth, thereby resulting in a higher percentage of culls.

Tomato stem and leaf dry weights and nitrogen uptake. Tillage significantly influenced stem and leaf dry weights and $\mathrm{N}$ uptake in 1996, and $\mathrm{N}$ fertilization influenced these parameters in 1996 and 1997 (Table 3). Interactions were significant for tillage $\times$ date of sampling (stem and leaf dry weights and $\mathrm{N}$ uptake in 1996), cover crop $\times \mathrm{N}$ fertilization $\times$ date of sampling (stem dry weight and $\mathrm{N}$ uptake in 1996), and cover crop $\times$ date of sampling and $\mathrm{N}$ fertilization $\times$ date of sampling (leaf $\mathrm{N}$ concentration in 1997).

In 1996, stem dry weight and $\mathrm{N}$ uptake were greater in plowed than in no-till plots from 40 to 118 DAT (Fig. 2 A and C). Similarly, leaf dry weight and N uptake were greater in plowed plots from 40 to 82 DAT (Fig. $3 \mathrm{~A}$ and $\mathrm{B}$ ). Stem weight and $\mathrm{N}$ uptake were also greater following $\mathrm{N}$ fertilization, regardless of the presence or absence of hairy vetch from 54 to 68 DAT (Fig. 2 B and D). In 1997, stem and leaf dry weights and leaf $N$ uptake were greater with 90 than with $0 \mathrm{~kg} \cdot \mathrm{ha}^{-1} \mathrm{~N}$ but stem $\mathrm{N}$ uptake was greater with 180 than with $0 \mathrm{~kg} \cdot \mathrm{ha}^{-1} \mathrm{~N}$ at 68 DAT (Table 4). Leaf $\mathrm{N}$ concentration was greater with than without hairy vetch at 82 and 104 DAT, and with than without $\mathrm{N}$ fertilization at 40, 55, and 92 DAT (Fig. 4 A and B).

Reduced root growth was also probably responsible for lower stem and leaf dry weights and $\mathrm{N}$ uptake in no-till plots in 1996. The nonsignificant difference between chisel and moldboard plowing suggests that sustained tomato growth can be achieved by using limited tillage. Chisel plowing can promote tomato root and shoot growth by subsoiling and breaking the hard pan below the plow layer (Univ. of Georgia, 1995).

The beneficial effects of $\mathrm{N}$ fertilization on stem dry weight and $\mathrm{N}$ uptake in 1996 and of

Table 3. Analysis of variance for dry weight, $\mathrm{N}$ concentration, and $\mathrm{N}$ uptake in tomato stems and leaves in 1996 and 1997.

\begin{tabular}{|c|c|c|c|c|c|c|}
\hline \multirow[b]{2}{*}{ Source $^{z}$} & \multicolumn{2}{|c|}{ Dry wt } & \multicolumn{2}{|c|}{$\mathrm{N}$ concn } & \multicolumn{2}{|c|}{$\mathrm{N}$ uptake } \\
\hline & Stems & Leaves & Stems & Leaves & Stems & Leaves \\
\hline \multicolumn{7}{|c|}{1996} \\
\hline Tillage (Till) & $* *$ & $* *$ & NS & NS & $* * *$ & * \\
\hline $\mathrm{N}$ fertilization (Fert) & $*$ & $*$ & NS & NS & $*$ & NS \\
\hline Date of sampling (Date) & $* * *$ & $* * *$ & $* * *$ & $* * *$ & $* * *$ & $* * *$ \\
\hline Till $\times$ Date & $* *$ & $* * *$ & NS & NS & $* *$ & $* * *$ \\
\hline Cover crop $($ Crop $) \times$ Fert $\times$ Date & $*$ & NS & NS & NS & $*$ & NS \\
\hline \multicolumn{7}{|c|}{1997} \\
\hline N Fertilization (Fert) & $* *$ & $*$ & NS & NS & $* * *$ & $*$ \\
\hline Date of sampling (Date) & $* * *$ & $* * *$ & $* * *$ & $* * *$ & $* * *$ & $* * *$ \\
\hline Cover crop $\times$ Date & NS & NS & NS & $*$ & NS & NS \\
\hline Fert $\times$ Date & NS & NS & NS & $*$ & NS & NS \\
\hline
\end{tabular}

${ }^{\mathrm{z}}$ Sources that were nonsignificant are excluded.

Ns, ***,**** Nonsignificant or significant at $P \leq 0.05,0.01$, and 0.001 , respectively.
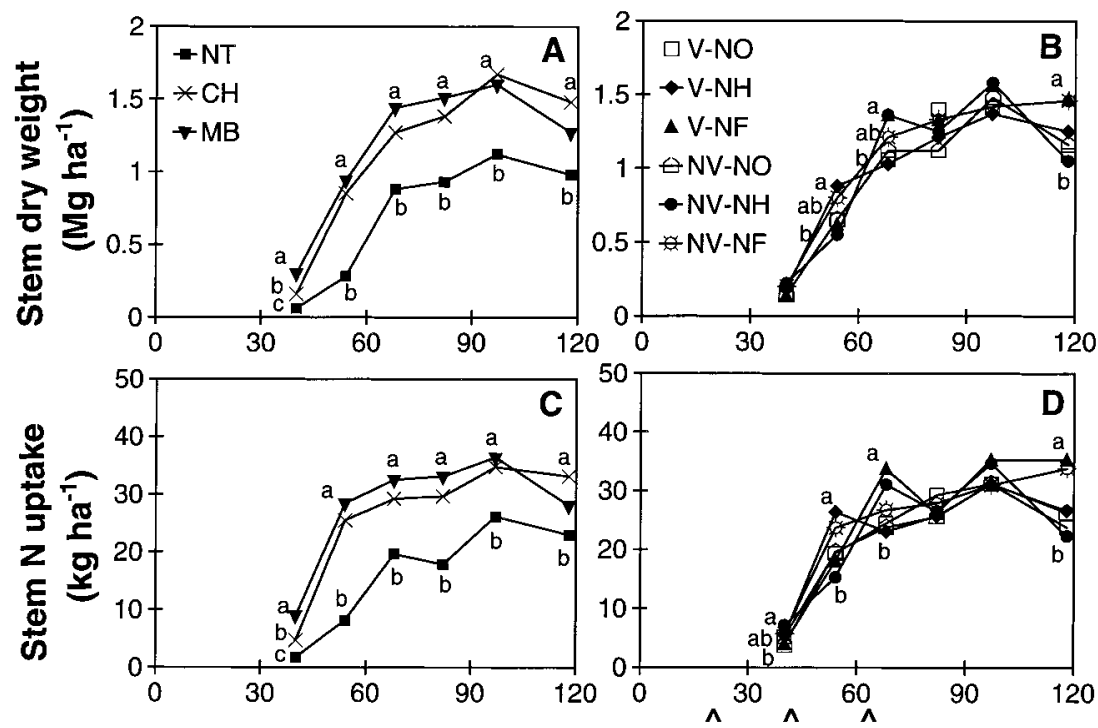

Days after transplanting

Fig. 2. Tomato stem dry weight and $\mathrm{N}$ uptake as influenced by tillage, cover cropping, and $\mathrm{N}$ fertilization in 1996. NT denotes no-till; $\mathrm{CH}$, chisel plowing; $\mathrm{MB}$, moldboard plowing; $\mathrm{V}$, hairy vetch; $\mathrm{NV}$, no hairy vetch; NO, $0 \mathrm{~kg} \cdot \mathrm{ha}^{-1} \mathrm{~N} ; \mathrm{NH}, 90 \mathrm{~kg} \cdot \mathrm{ha}^{-1} \mathrm{~N}$; and NF, $180 \mathrm{~kg} \cdot \mathrm{ha}^{-1} \mathrm{~N}$. Means separation by the least square means test, $P \leq 0.05$. $^{\wedge}$ denotes the time of $\mathrm{N}$ fertilization.

both $\mathrm{N}$ fertilization and hairy vetch on stem and leaf dry weights, $\mathrm{N}$ concentration, and $\mathrm{N}$ uptake in 1997 may reflect the promotive effects of $\mathrm{N}$ availability from $\mathrm{N}$ fertilizer or $\mathrm{N}$ mineralization from hairy vetch residue. Legume cover crops have increased tomato shoot growth and fruit yield (Abdul-Baki and Teasdale, 1993; Shennan, 1992; Stivers and Shennan, 1991; Teasdale and Abdul-Baki, 1995). Fertilization with $\mathrm{N}$ also increased tomato shoot growth (Melton and Dufault, 1991b; Weston and Zandstra, 1989; Widders, 1989). 

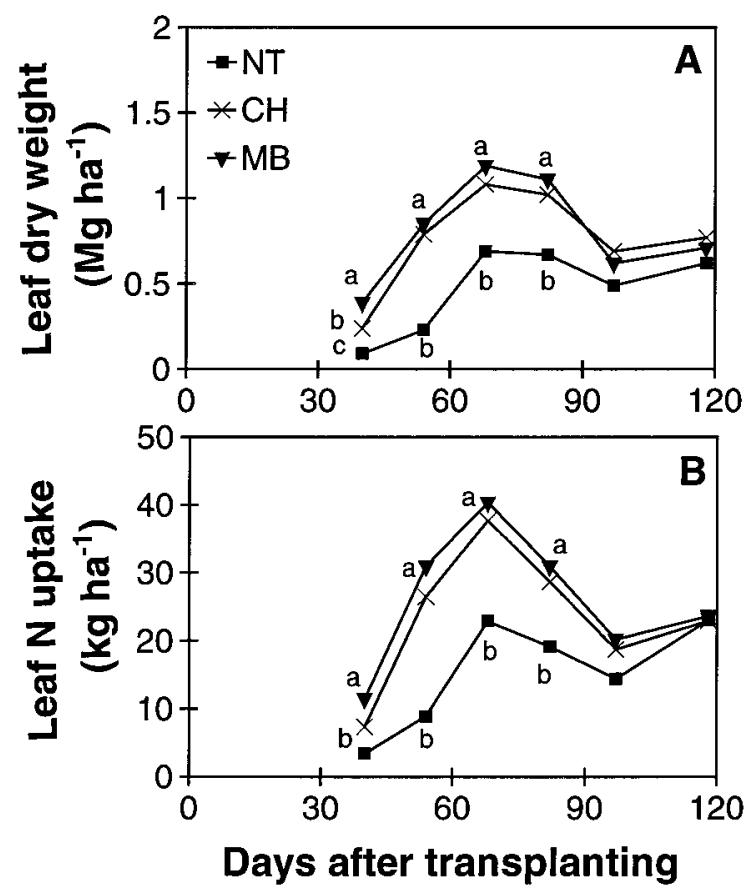

Fig. 3. Tomato leaf dry weight and $\mathrm{N}$ uptake as influenced by tillage in 1996 . NT denotes no-till; $\mathrm{CH}$, chisel plowing; and MB, moldboard plowing. Means separation by the least square means test, $P \leq 0.05$.

Table 4. Effects of $\mathrm{N}$ fertilization on tomato stem and leaf dry weights and $\mathrm{N}$ uptake at 68 d after transplanting in 1997.

\begin{tabular}{lllllr}
\hline \hline \multirow{2}{*}{$\begin{array}{l}\mathrm{N} \text { fertilization } \\
\left(\mathrm{kg} \cdot \mathrm{ha}^{-1}\right)\end{array}$} & \multicolumn{2}{c}{$\begin{array}{c}\text { Dry wt } \\
\left(\mathrm{Mg} \cdot \mathrm{ha}^{-1}\right)\end{array}$} & & \multicolumn{2}{c}{$\begin{array}{c}\text { N uptake } \\
\left(\mathrm{kg} \cdot \mathrm{ha}^{-1}\right)\end{array}$} \\
\cline { 2 - 3 } \cline { 5 - 6 } & Stems & Leaves & & Stems & Leaves \\
90 & $1.17 \mathrm{a}^{\mathrm{z}}$ & $1.13 \mathrm{a}$ & & $32.6 \mathrm{a}$ & $34.0 \mathrm{a}$ \\
180 & $1.35 \mathrm{~b}$ & $1.30 \mathrm{~b}$ & & $37.7 \mathrm{ab}$ & $46.1 \mathrm{~b}$ \\
& $1.32 \mathrm{ab}$ & $1.25 \mathrm{ab}$ & & $38.1 \mathrm{~b}$ & $42.1 \mathrm{ab}$ \\
\hline
\end{tabular}

${ }^{2}$ Mean separation within columns by the least square means test, $P \leq 005$.

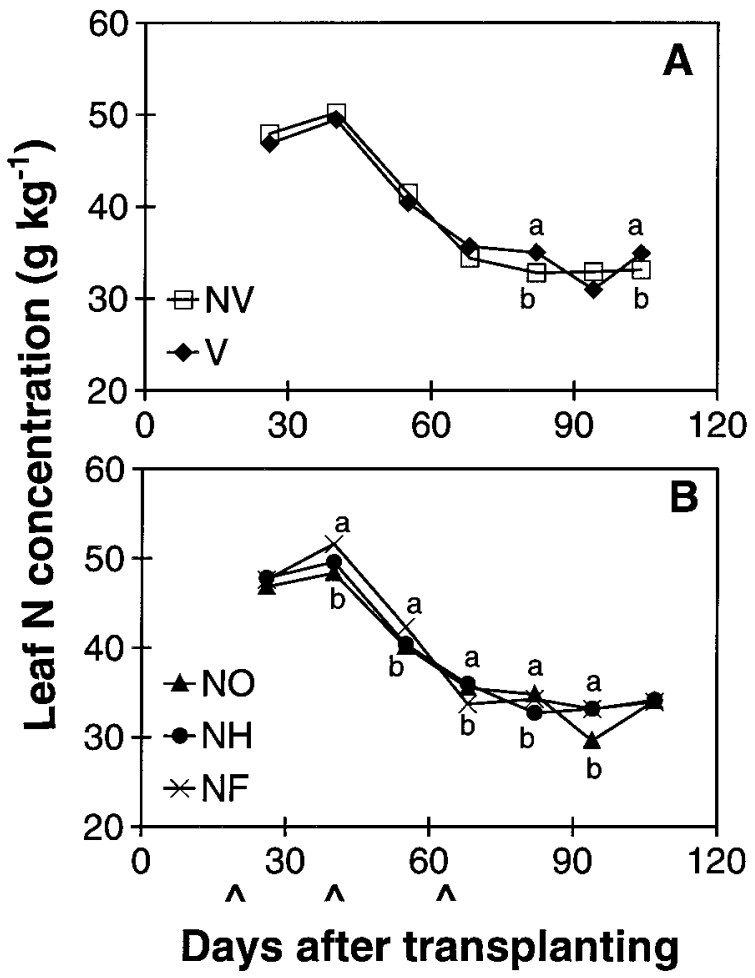

Fig. 4. Tomato leaf $\mathrm{N}$ concentration as influenced by cover cropping and $\mathrm{N}$ fertilization in 1997 . V denotes hairy vetch; NV, no hairy vetch; NO, $0 \mathrm{~kg} \cdot \mathrm{ha}^{-1} \mathrm{~N} ; \mathrm{NH}, 90 \mathrm{~kg} \cdot \mathrm{ha}^{-1} \mathrm{~N}$; and NF $180 \mathrm{~kg} \cdot \mathrm{ha}^{-1} \mathrm{~N}$. Means separation by the least square means test, $P \leq 0.05{ }^{\wedge} \wedge$ denotes the time of $\mathrm{N}$ fertilization.
The pattern of stem and leaf dry weights and $\mathrm{N}$ uptake (Figs. 2 and 3 ) indicates that tomatoes grew rapidly from 40 to 68 DAT. As fruiting occurred or leaves fell, growth was minimal. The decline in leaf $\mathrm{N}$ concentration with increasing maturity (Fig. 4) indicates a dilution effect with growth (Barker, 1989). Tiessen and Carolus (1963) found that $\mathrm{N}$ concentration in tomato shoot tissue decreased for several days after transplanting because of remobilization of $\mathrm{N}$ from shoot to root. In our study, however, leaf $\mathrm{N}$ concentration was higher in plots receiving $\mathrm{N}$ fertilizer.

Unlike fruit yield and $\mathrm{N}$ uptake, total stem and leaf dry weights at maximum growth stage (68 DAT) were $14 \%$ greater and $\mathrm{N}$ uptake was $29 \%$ greater in 1997 than in 1996, stem N concentration was $24 \%$ greater, and leaf $\mathrm{N}$ concentration was $4 \%$ greater. Increased rainfall from 40 to 120 DAT (Fig. 1) may have increased soil $\mathrm{N}$ mineralization and availability in 1997, thereby increasing tomato shoot growth and $\mathrm{N}$ uptake at the cost of fruit yield and $\mathrm{N}$ uptake.

Nitrogen recovery. Nitrogen recovered by tomato stems and leaves at 54 and 82 DAT was similar, but fruits recovered most (Table 5). Recovery increased from 54 to 82 DAT as fruits set. Total recovery of $\mathrm{N}$ by stems, leaves, and fruits from $\mathrm{N}$ supplied by hairy vetch ranged from $1 \%$ to $3 \%$ at 54 DAT and from $4 \%$ to $24 \%$ at 82 DAT. Total $\mathrm{N}$ recovery was 2fold greater with 90 than with $180 \mathrm{~kg} \cdot \mathrm{ha}^{-1} \mathrm{~N}$ in 1996 but the difference was not significant in 1997. Total $\mathrm{N}$ recovered from $\mathrm{N}$ fertilization ranged from $1 \%$ to $6 \%$ at 54 DAT and from $13 \%$ to $30 \%$ at 82 DAT. Regardless of N supplied by hairy vetch or $\mathrm{N}$ fertilization, recovery at 82 DAT was greater in 1997 than in 1996. Sweeney et al. (1987) reported that N recovered by tomato in Florida ranged from $32 \%$ to $53 \%$. This difference in $\mathrm{N}$ recovery could be due in part to variation in soil and climatic conditions and management practices.

Lower $\mathrm{N}$ recovery with hairy vetch residue than with $\mathrm{N}$ fertilization indicates that tomato was not able to utilize $\mathrm{N}$ supplied by the residue efficiently. Recovery with hairy vetch was, however, comparable with $\mathrm{N}$ fertilization at 82 DAT in 1997 (Table 5). Lower recovery with hairy vetch in 1996 than in 1997 probably resulted from decreased rainfall (Fig. 1), thereby influencing $\mathrm{N}$ mineralization from the residue. Even with $\mathrm{N}$ fertilization, the recovery was much less than the $32 \%$ to $53 \%$ found by Sweeney et al. (1987). Lower $\mathrm{N}$ recovery in tomato compared with the $50 \%$ value reported for most agronomic crops (Allison, 1955; Hallberg, 1989; Viets, 1965), suggests that N has greater potential to leach from the soil under tomato than under agronomic crops. Greater or similar N recovery with 90 than with $180 \mathrm{~kg} \cdot \mathrm{ha}^{-1} \mathrm{~N}$ indicates that no more than $90 \mathrm{~kg} \cdot \mathrm{ha}^{-1} \mathrm{~N}$ should be applied for tomato to sustain $\mathrm{N}$ recovery and to reduce $\mathrm{N}$ leaching.

\section{Conclusions}

Tomato yield and $\mathrm{N}$ uptake were affected by tillage, cover cropping, and $\mathrm{N}$ fertilization. 
Table 5. Percentage of $\mathrm{N}$ supplied by hairy vetch residue or $\mathrm{N}$ fertilization recovered by tomato stems, leaves, and fruits at 54 and 82 d after transplanting (DAT) in 1996 and 1997.

\begin{tabular}{|c|c|c|c|c|c|c|c|c|}
\hline \multirow[b]{2}{*}{ Treatment } & \multicolumn{2}{|c|}{ Stems } & \multicolumn{2}{|c|}{ Leaves } & \multicolumn{2}{|c|}{ Fruits } & \multicolumn{2}{|c|}{ Total } \\
\hline & 1996 & 1997 & 1996 & 1997 & 1996 & 1997 & 1996 & 1997 \\
\hline \multicolumn{9}{|c|}{$54 D A T$} \\
\hline Hairy vetch & 0.9 & 2.4 & 0.5 & 0.8 & --- & --- & 1.4 & 3.2 \\
\hline $90 \mathrm{~kg} \cdot \mathrm{ha}^{-1} \mathrm{~N}$ & 1.7 & 0.4 & 4.0 & 0.8 & --- & --- & 5.7 & 1.2 \\
\hline $180 \mathrm{~kg} \cdot \mathrm{ha}^{-1} \mathrm{~N}$ & 0.8 & 2.9 & 2.3 & 0.8 & --- & --- & 3.1 & 3.7 \\
\hline \multicolumn{9}{|c|}{$82 D A T$} \\
\hline Hairy vetch & 0.2 & 16.2 & 1.4 & 5.8 & 2.4 & 2.0 & 4.0 & 24.0 \\
\hline $90 \mathrm{~kg} \cdot \mathrm{ha}^{-1} \mathrm{~N}$ & 5.2 & 3.8 & 4.9 & 11.7 & 14.9 & 11.0 & 25.0 & 26.5 \\
\hline $180 \mathrm{~kg} \cdot \mathrm{ha}^{-1} \mathrm{~N}$ & 3.2 & 2.7 & 3.6 & 3.1 & 6.1 & 23.7 & 12.9 & 29.5 \\
\hline
\end{tabular}

While no-till decreased tomato fruit yield, stem and leaf dry weights, and $\mathrm{N}$ uptake compared with chisel or moldboard plowing in 1996, fruit yield, stem and leaf dry weights, and $\mathrm{N}$ uptake were not affected by the method of plowing in 1996 and 1997. Similarly, fertilization with Nincreased stem dry weight and $\mathrm{N}$ uptake at 54 to 68 DAT in 1996, whether or not hairy vetch was used, and increased fruit yield and $\mathrm{N}$ uptake in 1996 and 1997. However, 180 $\mathrm{kg} \cdot \mathrm{ha}^{-1} \mathrm{~N}$ was no more effective than $90 \mathrm{~kg} \cdot \mathrm{ha}^{-1}$ $\mathrm{N}$. Nitrogen recovery was lower with hairy vetch than with $\mathrm{N}$ fertilization but was not affected by the rate of $\mathrm{N}$ fertilization. For a sustained tomato production with reduced potentials of sediment and/or $\mathrm{NO}_{3}$ contamination in surface and groundwater, minimum tillage, such as chisel plowing, with $90 \mathrm{~kg} \cdot \mathrm{ha}^{-1}$ $\mathrm{N}$ are recommended.

\section{Literature Cited}

Abdul-Baki, A.A. and J.R. Teasdale. 1993. A notillage tomato production system hairy vetch and subterranean clover mulches. HortScience 28:106-108.

Allison, F.E. 1955. The enigma of soil nitrogen balance sheets. Adv. Agron. 7:213-250.

Barker, A.V. 1989. Genotypic responses of vegetable crops to nitrogen nutrition. HortScience 24:584-591.

Bauder, J.W., G.W. Randall, and J.B. Swan. 1981. Effects of four continuous tillage systems on mechanical impedance of a clay loam soil. Soil Sci. Soc. Amer. J. 45:802-806.

Berndt, M.P. 1993. National water quality assessment program. Preliminary assessment of nitrate distribution in groundwater in GeorgiaFlorida Coastal Plain study unit, 1972-1990. U.S. Geol. Surv., Earth Science Info. Ctr., Denver.

Dao, T.H. 1993. Tillage and winter wheat residue management effects on water infiltration and storage. Soil Sci. Soc. Amer. J. 57:1581-1595.

Frye, W.W., J.J. Varco, R.L. Blevins, M.S. Smith, and S.J. Corak. 1988. Role of annual legume cover crops in efficient use of water and nitrogen, p. 129-152. In: W.L. Hargrove (ed.). Cropping strategies for efficient use of water and nitrogen. ASA Spec. Publ. 51. ASA, CSSA, and SSSA, Madison, Wis

Hallberg, G.R. 1989. Nitrate in groundwater in the United States, p. 35-74. In: R.F. Follett (ed.). Nitrogen management and groundwater protection. Elsevier, Amsterdam.

Kaspar, T.C., H.J. Brown, and E.M. Kassmayer. 1991. Corn root distribution as affected by till- age, wheel traffic, and fertilizer placement. Soil Sci. Soc. Amer. J. 55:1390-1394.

Kuo S., U.M. Sainju, and E.J. Jellum. 1996. Winter cover cropping influence on nitrogen mineralization, presidedress soil nitrate test, and corn yields. Biol. Fertil. Soils 22:310-317.

Kuo, S., U.M. Sainju, and E.J. Jellum. 1997a. Winter cover crop effects on soil organic carbon and carbohydrate. Soil Sci. Soc. Amer. J. 61:145152.

Kuo, S., U.M. Sainju, and E.J. Jellum. 1997b. Winter cover cropping influence on nitrogen in soil. Soil Sci. Soc. Amer. J. 61:1392-1399.

Legg, J.O. and J.J. Meisinger. 1982. Soil nitrogen budgets, p. 503-566. In: F.J. Stevenson (ed.). Nitrogen in agricultural soils. Agron. Monogr. 22. ASA, CSSA, and SSSA, Madison, Wis.

Linville, K.W. and G.E. Smith. 1971. Nitrate content of soil cores from corn plots after repeated nitrogen fertilization. Soil Sci. 112:249-255.

Littell, R.C., G.A. Milliken, W.W. Stroup, and R.D. Wolfinger. 1996. SAS system for mixed models. SAS Inst., Cary, N.C.

Lowrance, R. and D. Smittle. 1988. Nitrogen cycling in a multiple crop-vegetable production system. J. Environ. Qual. 17:158-162.

McCarty, G.W., N.N. Lysenko, and J.L. Starr. 1998 Short-term changes in soil carbon and nitrogen pools during tillage transition management. Soil Sci. Soc. Amer. J. 62:1564-1571.

Meisinger, J.J., W.L. Hargrove, R.L. Mikkelsen, Jr., J.R. Williams, and V.W. Benson. 1991. Effects of cover crops on groundwater quality, p. 5768. In: W.L. Hargrove (ed.). Cover crops for clean water. Soil and Water Conserv. Soc., Ankeny, Iowa.

Meisinger, J.J., P.R. Shipley, and A.M. Decker. 1990. Using winter cover crops to recycle nitrogen and reduce leaching, p. 3-6. In: J.P. Mueller and M.G. Wagger (eds.). Conservation tillage for agriculture in the 1990's. Spec. Bul. 90-1. North Carolina State Univ., Raleigh.

Melton, R.R. and R.J. Dufault. 1991a. Tomato seedling growth, earliness, yield, and quality following pretransplant nutritional conditioning and low temperatures. J. Amer. Soc. Hort. Sci. 116:421-425.

Melton, R.R. and R.J. Dufault. 1991b. Nitrogen, phosphorus, and potassium fertility regimes affect tomato transplant growth. HortScience 26:141-142.

Merrill, S.D., A.L. Black, and A. Bauer. 1996 Conservation tillage affects root growth of dryland spring wheat under drought. Soil Sci. Soc. Amer. J. 60:575-583.

Owens, L.B., W.M.Edwards, and P.W. Van Keuren. 1994. Groundwater nitrate levels under fertilized grass and grass-legume pasture. J. Environ. Qual. 23:752-758.
Pang, X.P., S.C. Gupta, J.F. Moncrief, C.J. Rosen, and H.H. Cheng. 1998. Evaluation of nitrate leaching potential on Minnesota glacial outwash soils using the CERES maize model. J. Environ Qual. 27:75-85.

Power, J.F. and J.S. Schepers. 1989. Nitrate contamination of groundwater in North America. Agr. Ecosyst. Environ. 26:165-187.

Randall, G.W. 1990. Nitrate-nitrogen in the soil profile and tile drainage water as influenced by tillage. Amer. J. Ind. Med. 18:457-460.

Rao, S.C. and H. Dao 1996. Nitrogen placement and tillage effects on dry matter and nitrogen accumulation and redistribution in winter wheat. Agron. J. 88:365-371.

Sainju, U.M. and B.P. Singh. 1997. Winter cover crops for sustainable agricultural systems: Influence on soil properties, water quality, and crop yields. HortScience 32:21-28.

Sainju, U.M., B.P. Singh, and W.F. Whitehead. 1998. Cover crop root distribution and its effects on soil nitrogen cycling. Agron. J. 90:511-518.

Sexton, B.T., J.F. Moncrief, C.J. Rosen, S.C. Gupta, and H.H. Cheng. 1996. Optimizing nitrogen and irrigation input for corn based on nitrate leaching and yield on a coarse-textured soil. J. Environ. Qual. 25:982-992.

Shennan, C. 1992. Cover crops, nitrogen cycling, and soil properties in semi-irrigated vegetable production systems. HortScience 27:749-754.

Singh, B.P. and U.M. Sainju. 1998. Soil physical and morphological properties and root growth. HortScience 33:966-971.

Stivers, L.J. and C. Shennan. 1991. Meeting the nitrogen needs for processing tomatoes through winter cover cropping. J. Prod. Agr. 4:330-335.

Sweeney, D.W., D.A. Graetz, A.B. Bottcher, S.J. Locascio, and K.L. Campbell. 1987. Tomato yield and nitrogen recovery as influenced by irrigation method, nitrogen source, and mulch. HortScience 22:27-29.

Teasdale, J.R. and A.A. Abdul-Baki. 1995. Soil temperature and tomato growth associated black polyethylene and hairy vetch mulches. J. Amer. Soc. Hort. Sci. 120:848-853.

Tiessen, H. and R.L. Carolus. 1963. Effect of different analysis and concentration of fertilizer solutions on initial root growth of tomato and tobacco plants. Proc. Amer. Soc. Hort. Sci. 83:680683

University of Georgia. 1995. Commercial tomato production and management. Bul. 1116. Coop. Ext. Serv., Univ. of Georgia, Athens.

Viets, F.G. 1965. The plant's need for and use of nitrogen, p. 503-549. In: W.V. Bartholomew and F.E. Clark (eds.). Soil nitrogen. Agron. Monogr. 10. ASA and SSSA, Madison, Wis.

Voorhees, W.B. 1983. Relative effectiveness of tillage and natural forces in alleviating wheelinduced soil compaction. Soil Sci. Soc. Amer. J. 47:129-133.

Wander, M.M., M.G. Bidart, and S. Aref. 1998. Tillage impacts in depth distribution of total and particulate organic matter in three Illinois soils. Soil Sci. Soc. Amer. J. 62:1704-1711.

Weston, L.A. and B.H. Zandstra. 1989. Transplant age and $\mathrm{N}$ and $\mathrm{P}$ nutrition effects on growth and yield of tomatoes. HortScience 24:88-90.

Widders, I.E. 1989. Pretransplant treatments of N and $\mathrm{P}$ influence growth and elemental accumulation in tomato seedlings. J. Amer. Soc. Hort. Sci. 114:416-420.

Yadav, S.N. 1997. Formulation and estimation of nitrate-nitrogen leaching from corn cultivation. J. Environ. Qual. 26:808-814. 